DOI: http://dx.doi.org/10.33846/ghs5308

\title{
Pengetahuan Lansia tentang Osteoporosis di Desa Aek Uncim Kecamatan Borbor KabupatenToba Samosir
}

\author{
Marlon Sijabat (koresponden) \\ Dosen Program Studi Ilmu Keperawatan, Universitas Efarina \\ Josep Kristian \\ Dosen Program Studi Ilmu Keperawatan, Universitas Efarina
}

\section{ABSTRAK}

Osteoporosis banyak menyerang pada lansia, di Indonesia tahun 2007 hampir $74 \%$ terserang penyakit tersebut. Osteoporosis yang berarti "tulang keropos" adalah penyakit di mana tulang secara bertahap menjadi lemah dan rapuh. Tujuan penelitian adalah untuk mengetahui tingkat pengetahuan lansia tentang osteoporosis di Desa Aek Uncim Kecamatan Borbor Kabupaten Toba Samosir. Penelitian ini adalah penelitian deskriptif. Populasi dari penelitian ini adalah seluruh lansia yang berusia antara 60 tahun ke atas yang tinggal di Desa Aek yaitu sebanyak 123 orang. Peneliti mengambil sampel sebanyak 100 responden dengan menggunakan teknik simple randomized sampling. Dari hasil penelitian diperoleh tingkat pengetahuan lansia mengenai Osteoporosis secara umum di Desa Aek Uncim Kecamatan Borbor Kabupaten Toba Samosir sebanyak 60 responden $(60 \%)$ sudah memiliki tingkat pengetahuan yang baik, pengetahuan yang dikategori sedang sebesar $37 \%$ dan pengetahuan yang dikategori kurang sebesar 3\%. Untuk itu perlu dilakukan peningkatan pengetahuan masyarakat mengenai Osteoporosis terutama bagi lansia yang berpendidikan rendah, baik melalui puskesmas, posyandu lansia, dokter, media cetak, media elektronik maupun melalui penyuluhan.

Kata kunci: pengetahuan; lansia; osteoporosis

\section{PENDAHULUAN}

Pada saat seseorang menjadi tua akan mengalami proses menua. Proses menua merupakan proses sepanjang hidup, tidak hanya dimulai dari suatu kejadian tertentu, tetapi dimulai sejak permulaan kehidupan (Nugroho, 2008). Kecepatan proses menua setiap individu pada organ tubuh tidak akan sama. Adakalanya seseorang belum tergolong lanjut usia/ masih muda tetapi telah menunjukkan kekurangan yang mencolok. Ada pula orang yang telah tergolong lanjut usia, penampilannya masih sehat, segar bugar dan badan tegap (Nugroho, 2008).

Hasil analisa Depkes yang dilakukan di 14 propinsi menunjukkan masalah osteoporosis telah mencapai pada tingkat perlu diwaspadai yaitu sekitar 19,7 persen dari jumlah lansia yang ada. Faktor lain yang tak kalah penting adalah kurangnya pengetahuan dan kesadaran masyarakat untuk mencegah datangnya penyakit itu sendiri. Hal itu ditandai dengan rendahnya konsumsi kalsium ratarata orang Indonesia, yakni hanya $254 \mathrm{mg}$ per hari (Supari, S,F, 2005). Selain beberapa faktor diatas, pengetahuan seseorang juga sangat berpengaruh. Pengetahuan khusus sangat diperlukan, terutama pengetahuan mengenai osteoporosis dan asupan kalsium untuk mencegahnya (Mustopo, 2010).

Tujuan penelitian ini adalah untuk mengetahui pengetahuan lansia tentang osteoporosis di Desa Aek Uncim Kecamatan Borbor Kabupaten Toba Samosir.

\section{METODE}

Penelitian ini adalah penelitian deskriptif yang akan menggambarkan pengetahuan lansia tentang osteoporosis di Desa Aek Uncim Kecamatan Borbor, Kabupaten Toba Samosir. Penelitian ini dilakukan dengan pendekatan cross sectional dimana data diambil hanya sekali bagi tiap subyek pada saat wawancara.

Variabel dalam penelitian ini adalah tingkat pengetahuan tentang osteoporosis pada lansia. Lansia adalah seseorang yang sudah mencapai usia 60 tahun keatas. Pengetahuan tentang Osteoporosis adalah pengetahuan yang meliputi pengertian tentang Osteoporosis, faktor resiko terjadinya Osteoporosis, pencegahan dan terapi Osteoporosis. Alat ukur yang digunakan adalah kuesioner. Hasil pengukuran dinyatakan dalam tingkat pengetahuan yang dinyatakan dalam skala ordinal (ranking). 
HASIL

Dalam penelitian ini, responden yang terpilih adalah sebanyak 100 subjek. Dari keseluruhan responden, gambaran karakteristik responden yang diamati meliputi: umur, suku, tingkat pendidikan terakhir, pekerjaan dan penghasilan perbulan.

Tabel 1. Distribusi karakteristik responden di Desa Aek Uncim Kecamatan Borbor Kabupaten Toba Samosir $(n=100)$

\begin{tabular}{|c|c|c|}
\hline Karakteristik Responden & Frekuensi & Persentase \\
\hline $\begin{array}{c}\text { Umur (Tahun) } \\
60-74 \\
75-90 \\
\end{array}$ & $\begin{array}{l}64 \\
36 \\
\end{array}$ & $\begin{array}{l}64 \\
36 \\
\end{array}$ \\
\hline $\begin{array}{l}\text { Suku } \\
\quad \text { Batak }\end{array}$ & 100 & 100 \\
\hline $\begin{array}{l}\text { Pendidikan Terakhir } \\
\text { SD } \\
\text { SMP } \\
\text { SMA } \\
\text { Diploma/Sarjana }\end{array}$ & $\begin{array}{c}10 \\
36 \\
52 \\
2 \\
\end{array}$ & $\begin{array}{c}10 \\
36 \\
52 \\
2 \\
\end{array}$ \\
\hline Pekerjaan & & \\
\hline $\begin{array}{l}\text { Buruh } \\
\text { Wiraswasta } \\
\text { Pegawai negeri } \\
\text { lbu rumah tangga }\end{array}$ & $\begin{array}{l}23 \\
49 \\
15 \\
13 \\
\end{array}$ & $\begin{array}{l}23 \\
49 \\
15 \\
13 \\
\end{array}$ \\
\hline Penghasilan/bulan & & \\
\hline $\begin{array}{l}\text { <Rp. } 700.000,- \\
\text { Rp. } 700.000-\text { Rp. } 800.000,- \\
\text { Rp. } 800.000-\text { Rp. } 900.000,- \\
\text { Rp. } 900.000-\text { Rp. } 1.000 .000,- \\
\text { >Rp. } 1.000 .000,-\end{array}$ & $\begin{array}{c}6 \\
9 \\
18 \\
38 \\
29 \\
\end{array}$ & $\begin{array}{c}6 \\
9 \\
18 \\
38 \\
29 \\
\end{array}$ \\
\hline
\end{tabular}

Tabel 1 menunjukkan bahwa mayoritas responden berusia 60-74 tahun (64\%). Mayoritas responden adalah suku batak (100\%) dan pendidikan terakhir SMA (52\%). Responden memiliki pekerjaan sebagai wiraswasta (49\%) dan berpenghasilan sekitar 900.000-1.000.000 (38\%).

Data lengkap distribusi jawaban kuesioner responden pada variable pengetahuan dapat dilihat di tabel 2.

Tabel 2. Distribusi jawaban responden pada variabel pengetahuan di Desa Aek Uncim Kecamatan Borbor Kabupaten Toba Samosir $(n=100)$

\begin{tabular}{|l|l|c|c|}
\hline \multirow{2}{*}{ No } & Pernyataan & \multicolumn{2}{|l|}{ Jawaban } \\
\cline { 3 - 4 } & Ya: $f(\%)$ & Tidak: $f(\%)$ \\
\hline 1 & $\begin{array}{l}\text { Proses menua merupakan proses sepanjang hidup, tidak hanya } \\
\text { dimulai dari suatu waktu tertentu, tetapi dimulai sejak permulaan } \\
\text { kehidupan }\end{array}$ & $93(93)$ & $7(7)$ \\
\hline 2 & $\begin{array}{l}\text { Lanjut usia adalah seseorang yang mencapai usia 60 (enam } \\
\text { puluh) tahun ke atas }\end{array}$ & $84(84)$ & $16(16)$ \\
\hline 3 & $\begin{array}{l}\text { Osteoporosis banyak menyerang pada lansia } \\
\text { Osteoporosis merupakan kehilangan masa tulang (keropos } \\
\text { tulang) }\end{array}$ & $61(61)$ & $39(39)$ \\
\hline 5 & $\begin{array}{l}\text { Wanita lebih banyak dan mudah terkena Osteoporosis (keropos } \\
\text { tulang) dibanding laki-laki }\end{array}$ & $78(78)$ & $22(22)$ \\
\hline 6 & $\begin{array}{l}\text { Kurangnya aktivitas atau olahraga meningkatkan terjadinya } \\
\text { osteoporosis (keropos tulang) }\end{array}$ & $64(64)$ & $36(36)$ \\
\hline 7 & $\begin{array}{l}\text { Berkurangnya tinggi badan secara tiba-tiba merupakan tanda dan } \\
\text { gejala osteoporosis (keropos tulang) }\end{array}$ & $61(61)$ & $39(39)$ \\
\hline 8 & $\begin{array}{l}\text { Keju dan susu adalah makanan mengandung kalsium yang dapat } \\
\text { mencegah osteoporosis (keropos tulang) }\end{array}$ & $79(79)$ & $21(21)$ \\
\hline
\end{tabular}




\begin{tabular}{|l|l|c|c|}
\hline \multirow{2}{*}{ No } & Pernyataan & Jawaban \\
\cline { 2 - 4 } & Ya: f(\%) & Tidak: f (\%) \\
\hline 9 & Osteoporosis menyebabkan tubuh menjadi bungkuk & $79(79)$ & $21(21)$ \\
\hline 10 & $\begin{array}{l}\text { Pegal, linu, dan nyeri tulang merupakan tanda dan gejala } \\
\text { osteoporosis bagi lansia }\end{array}$ & $73(73)$ & $27(27)$ \\
\hline 11 & $\begin{array}{l}\text { Tulang yang pertama mengalami osteoporosis (keropos tulang) } \\
\text { adalah tulang belakang }\end{array}$ & $70(70)$ & $30(30)$ \\
\hline 12 & $\begin{array}{l}\text { Asupan kalsium yang cukup dapat mempertahankan kepadatan } \\
\text { tulang }\end{array}$ & $82(82)$ & $18(18)$ \\
\hline 13 & $\begin{array}{l}\text { Paparan sinar matahari pagi membantu tubuh menghasilkan } \\
\text { vitamin D yang membantu penyerapan kalsium dalam tubuh serta } \\
\text { mengatasi Osteoporosis (keropos tulang). }\end{array}$ & & $25(25)$ \\
\hline 14 & $\begin{array}{l}\text { Merokok dapat mempercepat osteoporosis (keropos tulang) } \\
\text { memperlambatkan osteoporosis (keropos tulang). }\end{array}$ & $66(66)$ & $34(34)$ \\
\hline 15 & $\begin{array}{l}\text { Orang yang konsumsi alkohol atau minuman keras dapat } \\
\text { mempl }\end{array}$ & $19(19)$ \\
\hline
\end{tabular}

Pertanyaan/pernyataan yang paling banyak dijawab benar adalah pertanyaan tentang pengertian proses menua merupakan proses sepanjang hidup, tidak hanya dimulai dari suatu waktu tertentu, tetapi dimulai sejak permulaan kehidupan sebanyak 93 orang sebesar $93 \%$. Sedangkan pertanyaan yang paling banyak dijawab salah adalah pertanyaan tentang osteoporosis banyak menyerang pada lansia dan berkurangnya tinggi badan secara tiba-tiba merupakan tanda dan gejala osteoporosis (keropos tulang) sebanyak 39 orang yaitu sebesar $39 \%$ dan juga soalan mengenai berkurangnya tinggi badan secara tiba-tiba merupakan tanda dan gejala osteoporosis (keropos tulang) sebanyak 39 orang yaitu sebesar $39 \%$.

Berdasarkan hasil uji tersebut, maka pengetahuan responden tentang Osteoporosis dapat dikategorikan pada tabel 3.

Tabel 3. Distribusi pengetahuan di Desa Aek Uncim Kecamatan Borbor Kabupaten Toba Samosir $(n=100)$

\begin{tabular}{|c|c|c|}
\hline Pengetahuan & Frekuensi & Persentase \\
\hline Baik & 60 & 60 \\
Sedang & 37 & 37 \\
Kurang & 3 & 3 \\
\hline Total & 100 & 100 \\
\hline
\end{tabular}

Pengetahuan dengan kategori baik memiliki persentase paling besar yaitu $60 \%$. Pengetahuan yang dikategori sedang sebesar 37\% dan tingkat pengetahuan yang dikategori kurang sebesar $3 \%$.

\section{PEMBAHASAN}

Menurut Roger (1974) dalam Notoadmojo (2012), pengetahuan atau kognitif merupakan domain yang sangat penting untuk terbentuknya tindakan seseorang. Dari hasil analisa data dapat dilihat bahawa pengetahuan masyarakat di Desa Aek Uncim Kecamatan Borbor Kabupaten Toba Samosir mengenai Osteoporosis berada dalam kategori baik, hal ini mungkin ada kaitannya dengan faktor usia yang dapat dilihat pada tabel 4 .

Tabel 4. Distribusi pengetahuan berdasarkan kelompok usia di Desa Aek Uncim Kecamatan Borbor Kabupaten Toba Samosir $(n=100)$

\begin{tabular}{|c|c|c|c|c|}
\hline Pengetahuan & Baik & Sedang & Kurang & \multirow{2}{*}{ Total } \\
\hline Usia & $\mathrm{f}(\%)$ & $\mathrm{f}(\%)$ & $\mathrm{f}(\%)$ & \\
\hline 60-74 Tahun & $45(45)$ & $19(19)$ & $0(0)$ & 64 \\
\hline 75-90 Tahun & $15(15)$ & $18(18)$ & $3(3)$ & 36 \\
\hline Total & $60(60)$ & $37(37)$ & $3(3)$ & 100 \\
\hline
\end{tabular}

Dari tabel 4 dapat dilihat bahwa pengetahuan yang dikategorikan baik paling banyak terdapat pada kelompok usia diantara 60-74 tahun (45\%), pengetahuan yang dikategorikan sedang paling banyak pada kelompok usia 60-74 tahun juga (19\%). Sedangkan pengetahuan yang kurang paling 
banyak terdapat pada usia 75-90 tahun (3\%). Dari hasil penelitian yang dilakukan oleh Ardita Popy Darwis dari Universitas Ponorogo Muhammadiyah (2008) Wanita premenopause memiliki pengetahuan buruk disebabkan karena rendahnya pendidikan, kurangnya informasi tentang osteoporosis dan bertambahnya usia.

Tabel 5. Distribusi Frekuensi dan Persentase tingkat pengetahuan berdasarkan tingkat pendidikan di Desa Aek Uncim Kecamatan Borbor Kabupaten Toba Samosir $(n=100)$

\begin{tabular}{|c|c|c|c|c|}
\hline Pengetahuan & Baik & Sedang & Kurang & \multirow{2}{*}{ Total } \\
\hline Pendidikan & $f(\%)$ & $f(\%)$ & $f(\%)$ & \\
\hline SD & $0(0)$ & $7(7)$ & $3(3)$ & 10 \\
\hline SLTP & $10(10)$ & $26(26)$ & $0(0)$ & 36 \\
\hline SLTA & $48(48)$ & $4(4)$ & $0(0)$ & 52 \\
\hline Diploma/Sarjana & $2(2)$ & $0(0)$ & $0(0)$ & 2 \\
\hline Total & $60(60)$ & $37(37)$ & $3(3)$ & 100 \\
\hline
\end{tabular}

Dari tabel 5 dapat dilihat bahawa pengetahuan yang baik paling banyak terdapat pada kelompok lulusan Sekolah Lanjutan Tingkat Atasan (48\%), tingkat yang dikategorikan sedang paling banyak pada kelompok lulusan Sekolah Lanjutan Tingkat Pertama (26\%). Sedangkan tingkat pengetahuan yang kurang paling banyak terdapat pada kelompok lulusan Sekolah Dasar saja (3\%). Dari hasil penelitian yang dilakukan oleh Ardita Popy Darwis dari Universitas Ponorogo Muhammadiyah (2008) dikatakan bahwa pada kelompok yang berpendidikan lebih tinggi akan memberikan tingkat pengetahuan tentang Osteoporosis yang lebih baik dibandingkan dengan kelompok pendidikan rendah.

Penelitian ini sesuai dengan penelitian yang dilakukan oleh Ardita Popy Darwis (2008), semakin tinggi pendidikan, semakin tinggi pula pengetahuan seseorang. Tingkat pendidikan yang tinggi akan meningkatkan cara seseorang memahami dan mengolah informasi Osteoporosis yang diperoleh dari berbagai sumber informasi seperti media cetak, media elektronik, dan penyuluhan dari petugas kesehatan. Banyaknya informasi yang diperoleh seseorang dari sumber-sumber informasi juga mempengaruhi pengetahuan seseorang. Selain itu faktor tempat tinggal terutama di perkotaan memudahkan masyarakat untuk memperoleh infomasi tentang Osteoporosis.

\section{KESIMPULAN}

Dari hasil penelitian ini dapat ditarik kesimpulan pengetahuan lansia mengenai Osteoporosis secara umum di Desa Aek Uncim Kecamatan Borbor Kabupaten Toba Samosir sudah memiliki pengetahuan yang baik yaitu sebanyak 60 responden $(60 \%)$, pengetahuan yang dikategori sedang sebesar $37 \%$ dan pengetahuan yang dikategori kurang sebesar $3 \%$.

\section{DAFTAR PUSTAKA}

1. Arikunto, S. (2010). Prosedur penelitian suatu pendekatan praktik. Cetakan 14. Jakarta: Rineka Cipta.

2. Azwar, S. (2005). Sikap manusia; Teori dan pengukurannya, Yogyakarta: Pustaka Pelajar.

3. Dalimartha. (2008). Gejala Osteoporosis dan Diagnosa Osteoporosis diakses dari http://www.medicastore.com/osteoporosis/gejala_osteoporosis.html pada tanggal 20 Januari 2014.

4. Darmojo, B.R, \& Martono, H.H. (2004). Buku ajar Geriatrik; Ilmu kesehatan lanjut usia, Jakarta: Balai Penerbit Fakultas Kedokteran Universitas Indonesia.

5. Darwis, A.P. (2008). Tingkat pengetahuan wanita premenopause tentang osteoporosis. Universitas Ponorogo Muhammadiyah, diakses dari www.google.com pada tanggal 25 Januari 2014.

6. Hamid, A. (2007). Penduduk lanjut usia di Indonesia dan masalah kesejahteraannya. Dibuka tanggal 27 Januari 2014 dari http://depsos.go.id

7. Harahap, M.H. (2006). Pengetahuan dan sikap remaja tentang HIV/ AIDS di Lingkungan XI Kelurahan Harjosari II Kecamatan Medan Amplas Sumatera Utara. Laporan Penelitian : Fakultas Keperawatan Universitas Sumatera Utara.

8. Hidayat, A.A.A. (2007). Metode penelitian keperawatan dan teknik analisis data, Jakarta: Salemba Medika. 
9. Anindya. (2009). Osteoporosis diakses dari http://www.pustaka-zikzik.co.cc/2009 /08/osteoporosis. html pada tanggal 24 Februari 2014.

10. Karolina, S.M. (2009). Hubungan pengetahuan dan pencegahan osteoporosis yang dilakukan lansia di Kecamatan Medan Selayang, diakses dari www.repositoryusu.com pada tanggal 20 Januari 2014.

11. Kawiyana, Siki. (2013). Osteoporosis Patogenesis Diagnosis Dan Penanganan Terkini. SMF Orthopaedi \& Traumatologi Bagian Bedah FK UNUD /RSUP Sanglah Denpasar diakses dari www.google.com pada tanggal 20 Januari 2014.

12. Lumbantoruan, S. (2010). Instrumen pendataan usaha ekonomi masyarakat. Pemko Binjai.

13. Maryam, S.M. (2009). Pengaruh keseimbangan fisik terhadap keseimbangan tubuh lansia di Panti Sosial Tresna Werdha Wilayah DKI Jakarta. Dibuka tanggal 04 Februari 2014 dari http://digilib.ui.ac.id

14. Maryam, S.R., Ekasari, F.M., Rosidawati, Jubaedi, A., \& Batubara, I. (2008). Mengenal usia lanjut dan perawatannya. Jakarta: Salemba Medika.

15. Mubarak, I.W., Chayatin, N., \& Santoso, A.B. (2009). Ilmu keperawatan komunitas; Konsep dan aplikasi, Jakarta: Salemba Medika.

16. Narayani, I. (2008). Hubungan tingkat pengetahuan keluarga terhadap sikap keluarga dalam pemberian perawatan activities daily living (ADL) di rumah desa Tanjungrejo Margoyoso Pati. Dibuka tanggal 04 Februari 2014 dari http://etd.eprints.ums.ac.id

17. Nidhea. (2013). Mengapa Lansia Sering Tiba-Tiba Roboh. Dibuka tanggal 24 Januari 2014 dari www.republika.co.id

18. Notoatmodjo, S. (2010). Pendidikan dan perilaku kesehatan. Jakarta: Rineka Cipta.

19. Nugroho, W. (2000). Keperawatan gerontik. Jakarta: Penerbit Buku Kedokteran EGC

20. Nugroho, W. (2008). Gerontik \& Geriatrik. Jakarta: Penerbit Buku Kedokteran EGC.

21. Nursalam, (2003). Konsep \& penerapan metodologi penelitian ilmu keperawatan : Pedoman skripsi, tesis dan instrumen penelitian keperawatan. Jakarta: Salemba Medika.

22. Polit, D.F \& Hungler, B.P. (1995). Nursing Research Principles and Methods Fifth Edition. Philadhelphia: J.B. Lippincot Company.

23. Purwanto, H. (2009). Pengantar perilaku manusia untuk keperawatan. Jakarta: Penerbit Buku Kedokteran EGC.

24. Setiawati, B. (2009). Kesabaran anak dalam merawat orangtua yang sakit kronis. Dibuka pada tanggal 4 Juli 2012 dari http://etd.eprints.ums.ac.id.

25. Setiawati, S., \& Dermawan, C.A. (2008). Penuntun praktis asuhan keperawatan keluarga. Jakarta: Trans Info Media.

26. Suhartono, S. (2008). Filsafat ilmu pengetahuan. Yogyakarta: Ar-Ruzz Media

27. Susanti, T. (2009). Hubungan antara tingkat pengetahuan keluarga dengan sikap keluarga usia lanjut dalam pencegahan jatuh di rumah di Dusun Gamping Kidul Ambar Ketawang Sleman Yogyakarta. Dibuka pada tanggal 14 Januari 2014 dari http://publikasi.umy.ac.id

28. Widayatun, R., T. (2009). Ilmu perilaku. Jakarta: Sagung Seto 